\title{
PEMANFAATAN LIMBAH BAGLOG JAMUR TIRAM SEBAGAI BAHAN BAKU BIO BRIKET DI DESA POLOKARTO SUKOHARJO JAWA TENGAH
}

\author{
Retno Wulan Damayanti ${ }^{1}$, Rahmaniyah Dwi Astuti ${ }^{1}$ dan Haryono Setiadi ${ }^{2}$ \\ ${ }^{1}$ Fakultas Teknik Universitas Sebelas Maret \\ ${ }^{2}$ Fakultas Teknik Universitas Sebelas Maret \\ ${ }^{3}$ Fakultas MIPA Universitas Sebelas Maret \\ rwd@ft.uns.ac.id, hsd@staff.uns.ac.id
}

\begin{abstract}
Abstrak
Pembudidaya jamur tiram di Polokarto teridentifikasi memiliki permasalahan terkait dengan limbah media baglog jamur tiram. Media baglog setelah melewati usia produktif (rata-rata 4 bulan) akan menjadi limbah padat dan dibuang begitu saja. Limbah media tersebut dapat diolah menjadi bio briket sehingga memiliki nilai ekonomis bagi para pembudidaya. Berdasarkan permasalahan tersebut, solusi yang diberikan terdiri dari dua pendekatan, yaitu solusi teknologi dan manajemen. Solusi teknologi adalah dengan mengimplementasikan fasilitas produksi bio briket yang terdiri dari alat pengepress dan kompor bio briket. Solusi manajemen yaitu pada kegiatan implementasi ini, mitra diberikan sosialisasi, pelatihan dan pendampingan untuk melakukan produksi bio briket, melakukan perawatan alat produksi, mengemas dan memasarkan bio briket. Selama kegiatan, para pembudidaya dilibatkan secara aktif mulai dari proses pengembangan alat hingga implementasinya. Hal ini bertujuan agar mitra memiliki kesadaran untuk menggunakan, merawat dan memanfaatkan teknologi yang telah diaplikasikan. Hasil kegiatan ini, mitra pembudidaya telah mampu memproduksi dan memasarkan bio briket dari limbah baglog jamur tiram.
\end{abstract}

Kata Kunci: bio briket, jamur tiram, limbah baglog

\section{PENDAHULUAN}

Jamur tiram putih (Pleurotus ostreatus) merupakan komoditi yang mempunyai prospek sangat baik untuk dikembangkan, baik untuk mencukupi pasaran dalam negeri yang terus meningkat maupun untuk ekspor. Selain proses budidaya yang tergolong mudah, jamur tiram juga diminati pasar karena memiliki kandungan gizi dan nutrisi yang baik serta kandungan anti oksidan yang sangat bermanfaat bagi kesehatan tubuh manusia [1]. Jamur tiram putih tergolong jamur yang banyak diminati oleh konsumen karena kaya akan nutrisi baik untuk gizi makanan, serta memiliki rasa yang lezat seperti daging ayam, tekstur yang lembut, dan warna yang bersih. Tampilan jamur tiram putih disajikan pada Gambar 1.

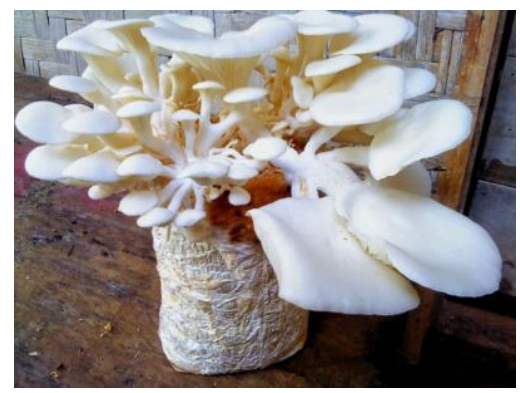

Gambar 1. Tampilan Jamur Tiram Putih 
Beberapa sentra pembudidaya jamur tiram di Jawa Tengah antara lain tersebar di Jepara, Purworejo, Sukoharjo, dan Boyolali [2]. Daerah Sukoharjo yang dikenal sebagai wilayah penghasil jamur tiram putih adalah Desa Polokarto. Desa ini berada pada ketinggian $400 \mathrm{~m} \mathrm{dpl}$, dengan iklim tropis, kisaran suhu $250 \mathrm{C}-280 \mathrm{C}$ dan kelembaban udara mencapai $88 \%$. Pada kondisi ini, wilayah Desa Polokarto sangat sesuai untuk tumbuh kembang jamur tiram putih tanpa perlu lagi dilakukan rekayasa lingkungan untuk mengkondisikan pembudidayaan jamur tiram putih. Aktivitas budidaya di Desa ini telah dilakukan sejak tahun 2008 dan hingga saat ini hampir seluruh penduduk desa melakukan aktivitas usaha budidaya jamur tiram.

Proses budidaya jamur tiram secara garis besar dimulai dengan tahapan pembuatan media tanam (baglog) jamur tiram, inkubasi baglog di dalam kumbung, dan tahapan pemanenan. Media tanam jamur (baglog) ini terbuat dari campuran serbuk gergaji, bekatul, kapur, dan bibit jamur. Untuk menghasilkan 1000 baglog, proses pencampuran dilakukan selama kurang lebih 3 jam dengan 2 tenaga manusia. Proses pencampuran media tumbuh jamur tiram oleh pembudidaya ditampilkan pada Gambar 2.
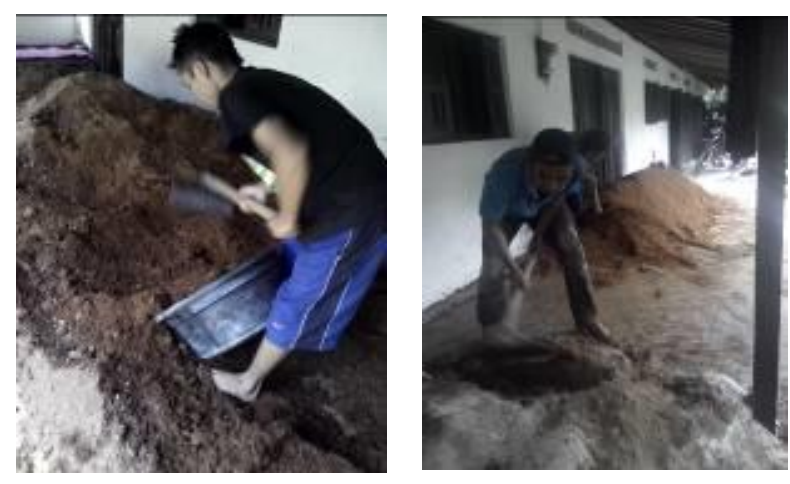

Gambar 2. Proses Pencampuran Media Tumbuh Jamur Tiram

Tahapan berikutnya setelah pencampuran media tumbuh jamur tersebut, yaitu pengemasan dan pemadatan media tumbuh jamur di dalam plastik baglog. Para pembudidaya jamur tiram telah memiliki alat untuk pengepresan baglog ini, yang ditampilkan pada Gambar 3.
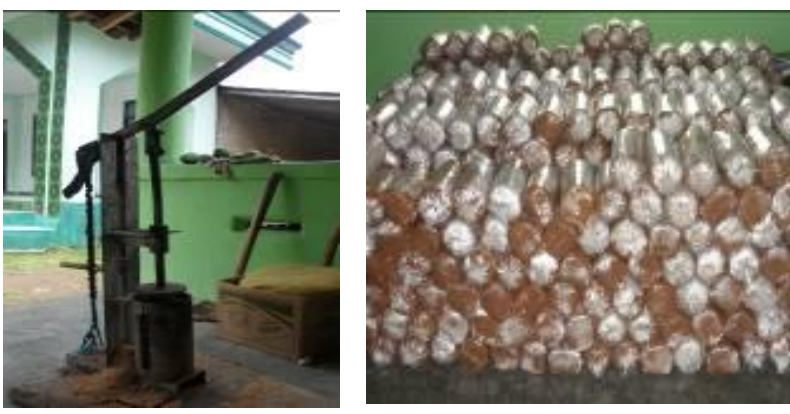

Gambar 3. Alat Pengepres Baglog dan Hasilnya

Setelah baglog dipress, proses selanjutnya adalah sterilisasi. Sterilisasi dilakukan dengan memanaskan baglog di dalam oven dengan suhu $121^{\circ} \mathrm{C}$. Oven yang dimiliki oleh para pembudidaya adalah berupa bangunan batu bata berukuran $2 \times 1,5$ $\mathrm{m}$, dengan konsep steamer (dipapar dengan uap panas). Sistem steamer dilakukan dengan memanaskan air di dalam drum, yang kemudian uap panas hasil pemanasan tersebut dialirkan masuk ke dalam ruangan oven untuk memanaskan baglog. Cara ini cukup efektif dan aman karena api terpisah dari baglog yang disterilkan. Proses sterilisasi baglog di lokasi pembudidaya jamur tiram ditampilkan pada Gambar 4.
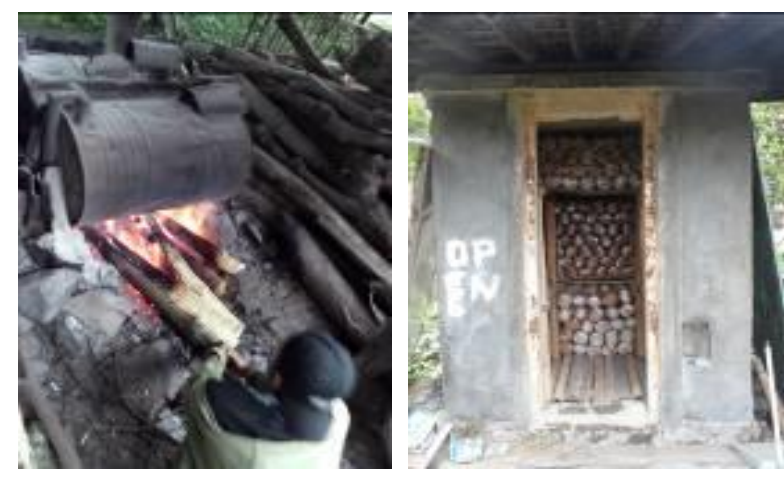

Gambar 4. Proses Sterilisasi Baglog di dalam Oven

Setelah proses sterilisasi di dalam oven, selanjutnya baglog didinginkan hingga mencapai suhu ruangan $\left(27^{\circ} \mathrm{C}\right)$, kemudian baglog ditata di kumbung jamur untuk proses inkubasi. Proses inkubasi ini berlangsung selama 2 minggu, sebelum akhirnya jamur tiram tumbuh dan siap panen. Kumbung jamur di lokasi pembudidaya ditampilkan pada Gambar 5. 


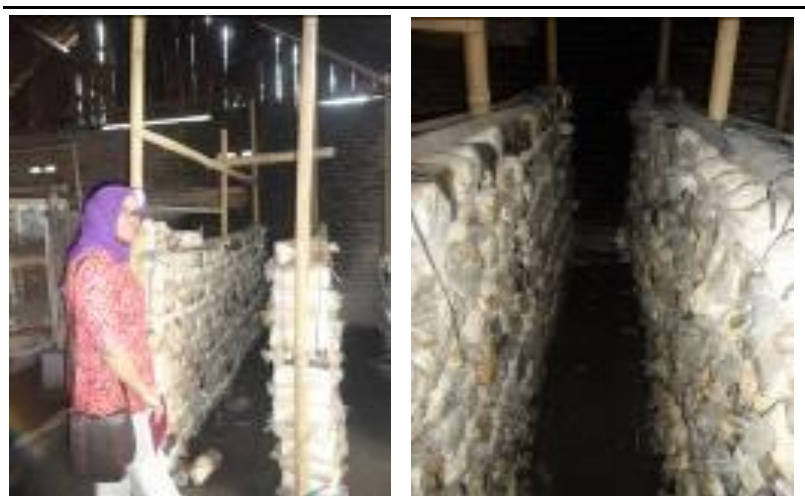

Gambar 5. Kumbung Jamur di Lokasi Pembudidaya Jamur

Rata-rata usia produktif media baglog jamur tiram putih adalah 4 bulan. Setelah melewati usia produktif, media baglog jamur tiram putih akan menjadi limbah padat. Limbah media baglog jamur tiram putih belum dimanfaatkan secara ekonomis dan optimal[3]. Limbah media baglog jamur tiram hanya digunakan untuk pupuk tanaman bahkan banyak yang hanya dibuang begitu saja[4].

Komposisi media baglog jamur terdiri atas $80 \%$ serbuk gergaji, $10 \%$ dedak padi, 1,8\% kapur, $1,8 \%$ gipsum dan 0,4\% TS[5]. Berdasarkan komposisi limbah baglog jamur dengan $80 \%$ serbuk gergaji dan $10 \%$ dedak padi yang ada dalam baglog jamur merupakan bahan baku superkarbon [6]. Contoh limbah baglog di tampilkan pada Gambar 6 .

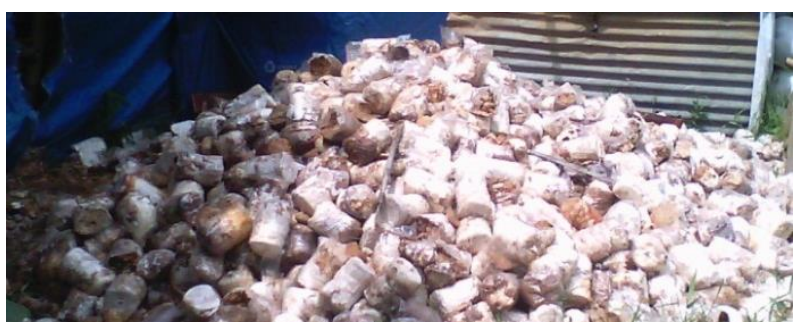

Gambar 6. Limbah Baglog Jamur Tiram

Materi limbah dari sisa miselia media baglog tersebut dapat mengalami pembusukan dan pelepasan $\mathrm{CH} 4$ (gas metana) ke udara secara percuma yang dapat mengakibatkan pencemaran [7]. Limbah yang dibuang ini rawan menjadi sarang hama dan penyakit yang sewaktu-waktu menyerang usaha budidaya jamur, pembibitan jamur, tanaman pertanian, ternak dan manusia. Limbah tersebut juga memberikan pemandangan yang mengganggu estetika lingkungan.
Berdasarkan diskusi yang dilakukan oleh Tim Program Kemitraan Masyarakat (PKM) Universitas Negeri Sebelas Maret Surakarta (UNS) dengan para pembudidaya jamur di desa Polokarto, hasil produksi baglog per hari mencapai \pm 800 baglog yang selalu habis digunakan, baik untuk budidaya kelompok tani tersebut maupun terjual kepada mitra petani jamur lainnya. Setelah empat bulan, media baglog tersebut harus diperbaharui dengan baglog yang baru. Setiap 1 kantong lterna limbah baglog menghasilkan $\pm 0.5 \mathrm{~kg}$. Artinya setiap kali proses pembaharuan baglog baru dengan kumbung yang berisi 5000 baglog, akan menghasilkan $2500 \mathrm{~kg}(2,5$ ton) limbah baglog jamur.

Kandungan energi yang terdapat dalam material lterna (limbah budi daya jamur) tersebut sesungguhnya masih dapat dimanfaatkan sehingga tidak terbuang ke udara secara percuma [8] dan berpotensi untuk dijadikan bio briket superkarbon sebagai pengganti bahan bakar [9]. Superkarbon adalah bahan baku karbon dalam bentuk briket yang diproduksi dari bahan limbah alternatif maupun turunannya yang masih mengandung sumber energi [6].

Bio briket merupakan salah satu cara yang digunakan untuk mengkonversi sumber energi biomassa ke bentuk biomassa lain dengan cara dimampatkan sehingga bentuknya menjadi lebih teratur [10]. Penggunaan bio briket dapat mengurangi pencemaran lingkungan karena bahan alternatif tidak menghasilkan emisi gas beracun, seperti Nox dan Sox.

Berdasarkan uraian yang telah dipaparkan, permasalahan pembudidaya jamur di Desa Polokarto adalah berkaitan dengan limbah media baglog yang belum dimanfaatkan secara optimal. Solusi untuk menyelesaikan permasalahan tersebut adalah dengan mengolah limbah baglog jamur tiram menjadi bio briket. Selain dapat dimanfaatkan sendiri oleh pembudidaya jamur tiram sebagai bahan bakar proses sterilisasi media baglog, bio briket tersebut juga dapat dijual kepada masyarakat umum sebagai bahan bakar alternatif penganti minyak bumi. 


\section{METODE}

Penyelesaian masalah bagi pembudidaya jamur tiram, dilakukan melalui dukungan teknologi dan dukungan manajemen. Solusi teknologi dilakukan dengan implementasi fasilitas produksi bio briket limbah baglog jamur tiram. Solusi manajemen dilakukan dengan melakukan sosialisasi, pelatihan, dan pendampingan saat produksi bio briket, perawatan alat produksi, dan penggunaan serta pengemasan bio briket. Setiap kegiatan tersebut dilakukan dengan melibatkan dan memberdayakan secara aktif para mitra pembudidaya. Tahapan umum metode kegiatan dipaparkan pada Gambar 7.

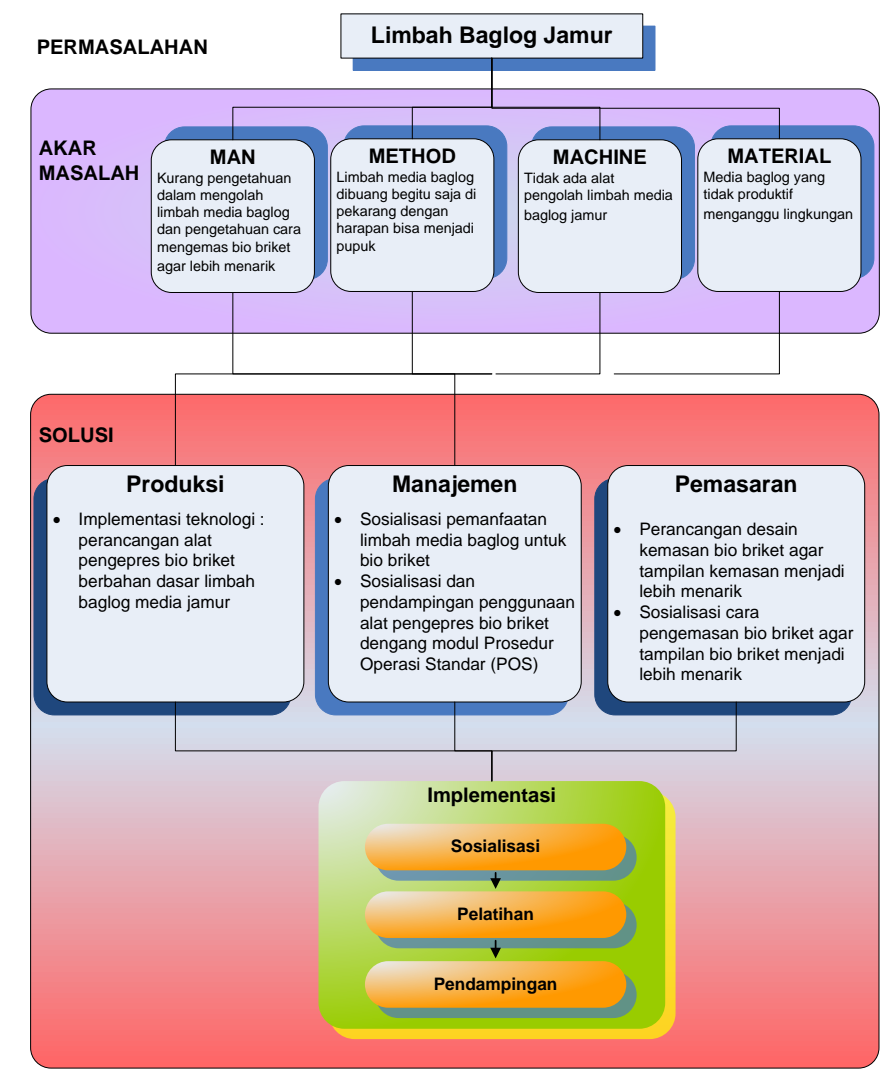

Gambar 7. Metode Penyelesaian Permasalahan Mitra

Rincian penjelasan dari masing-masing metode dipaparkan sebagai berikut:

\section{a. Metode Pelaksanaan Kegiatan Terkait Solusi Teknologi}

Solusi teknologi untuk mendukung aspek produksi bio briket limbah baglog jamur tiram yaitu dengan implementasi teknologi alat pengepres bio briket yang digunakan untuk memadatkan limbah media baglog dan kompor briket. Alat pengepres dan kompor briket ini merupakan hasil riset dan pengembangan yang dilakukan oleh tim peneliti dari Riset Group Pusat Kajian Pengembangan Teknologi dan Kolaborasi Industri (PKPTKI) Lembaga Penelitian dan Pengabdian Masyarakat (LPPM) UNS.

Pada kegiatan ini, mitra pembudidaya terlibat dalam penyempurnaan rancang bangun alat pengepres limbah media baglog dan kompor briket. Mitra terlibat dalam pemberian masukan (feedback) berkaitan dengan fungsionalitas alat. Hal ini bertujuan agar alat hasil rancangan dapat diperbaiki dan dikembangkan lagi. Mitra juga terlibat langsung dalam tahap uji coba dan evaluasi alat pengepres limbah media baglog yang telah dikembangkan.

\section{b. Metode Pelaksanaan Kegiatan Terkait Permasalahan Manajemen}

Implementasi teknologi kepada pembudidaya perlu diikuti dengan dukungan manajemen (pengelolaan) teknologi tersebut. Berkaitan dengan permasalahan manajemen ini, solusi yang diberikan adalah: sosialisasi, pelatihan, pendampingan penggunaan serta perawatan fasilitas produksi bio briket (alat press dan kompor). Selain itu juga akan dilakukan sosialisasi dan pelatihan aplikasi bio briket dan bagaimana cara mengemas bio briket untuk dipasarkan sebagai bahan bakar alternatif pengganti minyak bumi.

Rincian aktivitas dari setiap kegiatan ditampilkan pada Gambar 8. 


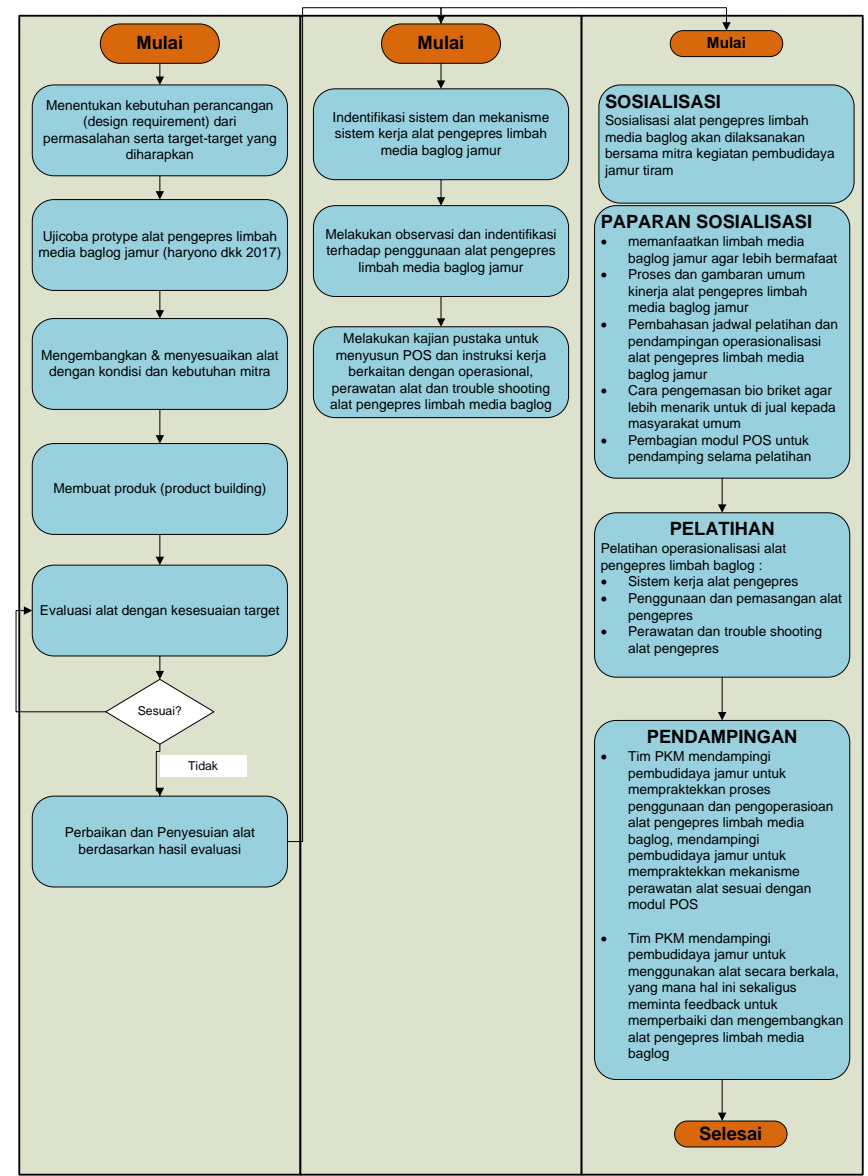

Gambar 8. Rencana Prosedur Kegiatan

\section{HASIL DAN PEMBAHASAN}

Ipteks yang diaplikasikan kepada mitra terdiri dari teknologi tepat guna dan manajemen alat pengepres bio briket yang digunakan untuk memadatkan limbah media baglog, kompor briket, dan rancangan kemasan untuk pemasaran bio briket. Hasil implementasi teknologi dan manajemennya dipaparkan sebagai berikut:

\section{Implementasi Alat Pengepres dan Kompor Bio Briket}

Alat pengepres bio briket yang diimplementasikan adalah alat pengepres bio briket sistem manual. Sistem mekanisme penggeraknya menggunakan cara manual yaitu dengan diputar pada bagian pemutar atas (bagian atas alat pengepres bio briket dilengkapi dengan besi bulat sebagai tempat untuk memutar, dan besi bulat tersebut dihubungkan dengan piston).
Spesifikasi teknis dari alat pengepress yaitu : spesifikasi: bahan rangka besi UNP-100, tenaga penggerak manual dengan menggunakan tangan dan dimensi panjang $60 \mathrm{~cm}$, lebar $70 \mathrm{~cm}$, tinggi $120 \mathrm{~cm}$. Alat ini merupakan hasil rancangan tim PKPTKI LPPM UNS tahun 2018.

Komposisi bio briket yang diproduksi terdiri dari serbuk gergaji (baglog) jamur 65\%, arang yang ditumbuk halus $25 \%$ dan tepung kanji $10 \%$. Komposisi ini dirumuskan berdasarkan kajian yang telah sebelumnya oleh tim PKPTKI LPPM UNS yang berpotensi diaplikasikan di lokasi mitra pembudidaya.

Sebelum diaplikasikan kepada mitra, alat tersebut diujicoba untuk memastikan kinerjanya. Proses ujicoba alat dilakukan langsung bersama dengan mitra. Aktivitas tersebut ditampilkan pada gambar 9 .
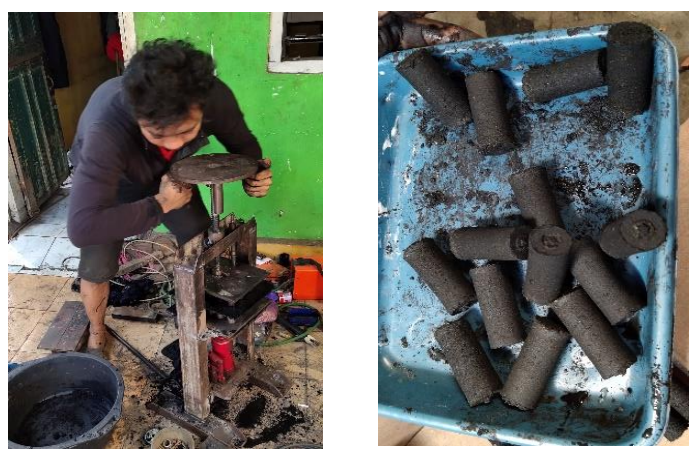

Gambar 9. Proses Uji Coba Alat Pengepres Bio Briket

Bio briket hasil uji coba kemudian di keringkan dengan panas matahari selama 24 jam sampai kondisi bio briket menjadi kering. Setelah proses pengeringan selesai, kemudian dilakukan pengujian pembakaran bio briket dengan menggunakan kompor khusus bio briket. Kompor bio briket memiliki spesifikasi diamater $20 \mathrm{~cm}$ dan tinggi $30 \mathrm{~cm}$.

Hasil uji coba, bio briket dapat terbakar secara sempurna. Proses pengujian pembakaran bio briket dengan mitra ditampikan pada gambar 10. 

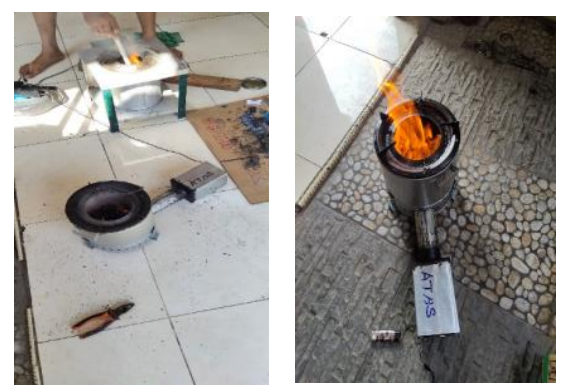

Gambar 10. Proses Uji Coba Pembakaran Bio Briket Pada Kompor dengan mitra

Selanjutnya alat pengepress dan kompor diujicoba oleh mitra secara mandiri untuk produksi bio briket. Proses aplikasi alat pengepres bio briket di tempat mitra pembudidaya jamur tiram ditampilkan pada gambar 11.
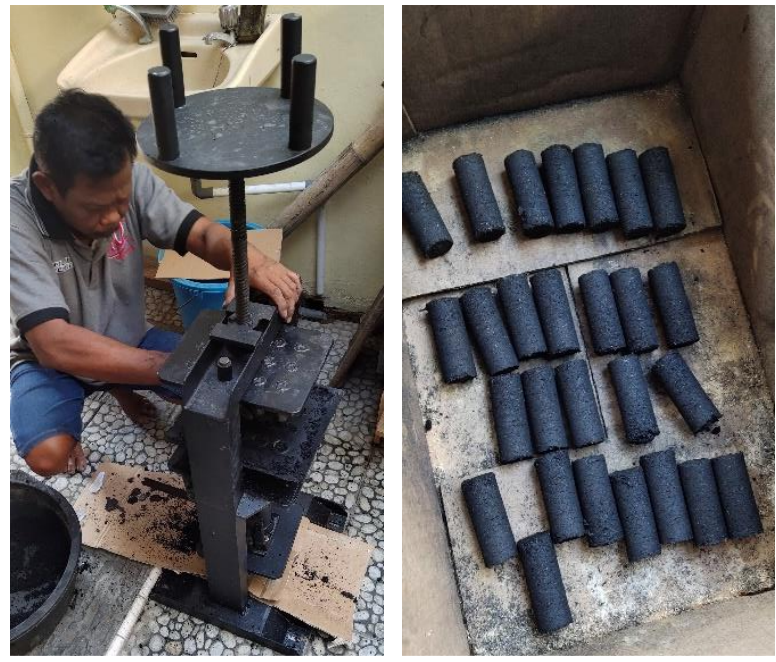

Gambar 11. Proses Uji Coba Alat Pengepres Bio Briket di Lokasi Mitra Pengabdian

\section{Rancangan Desain Kemasan Bio Briket}

Pembuatan alat pengepres akan menghasilkan produk berupa bio briket yang nantinya selain bisa digunakan sendiri untuk bahan bakar proses sterilisasi atapun dijual kepada masyarakat umum sebagai bahan bakar alternatif penganti minyak bumi. Agar tampilan dari kemasan bio briket menarik, tim kegiatan melakukan pembuatan desain kemasan bio briket. Tampilan dari desain kemasan bio briket yang dibuat ditampilkan pada gambar 12 .

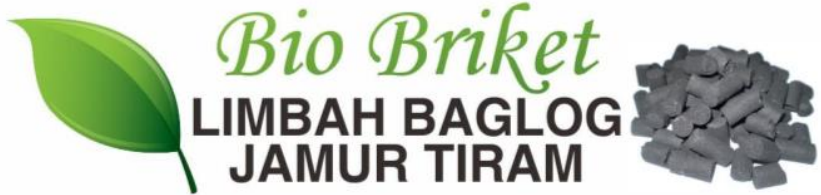

KOMPOSISI:

- LIMBAH BAGLOG JAMUR

- ARANG KELAPA

TEPUNG KANJI

DIPRODUKSI OLEH: PETANI JAMUR TIRAM DENOKAN, POLOKARTO,

Gambar 12. Desain Kemasan Bio Briket

\section{Aktivitas Manajerial: Sosialisasi, Pelatihan, dan Pendampingan}

Selain penerapan teknologi tepat guna berupa alat pengepres dan kompor bio briket. Mitra pembudidaya jamur tiram juga didukungan dari sisi manajemen. Berkaitan dengan dukungan manajemen ini, tim PKM UNS memberikan sosialisasi, pelatihan dan pendampingan penggunaan dan perawatan alat produksi bio briket serta pemasaran bio briket kepada kelompok pembudidaya jamur tiram di Desa Polokarto.

Kegiatan tersebut dilaksanakan secara bertahap yang meliputi sosialisasi dan pelatihan selama 1 hari. Kegiatan pendampingan dilakukan selama 2 bulan dengan kunjungan periodik setiap minggu. Beberapa kegiatan aktivitas ini ditampilkan pada gambar 13.

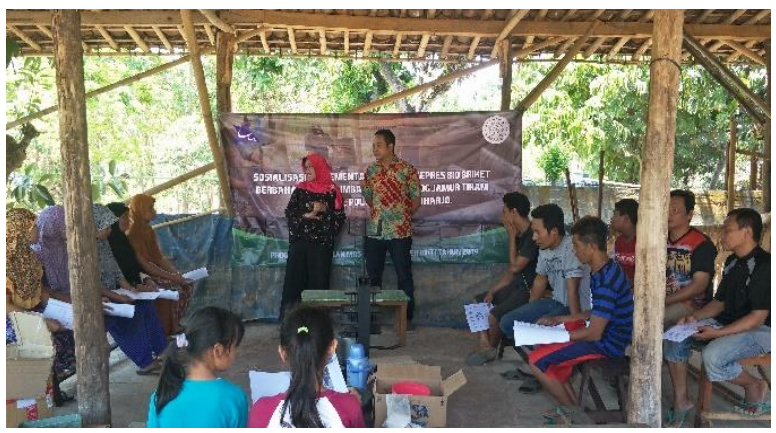



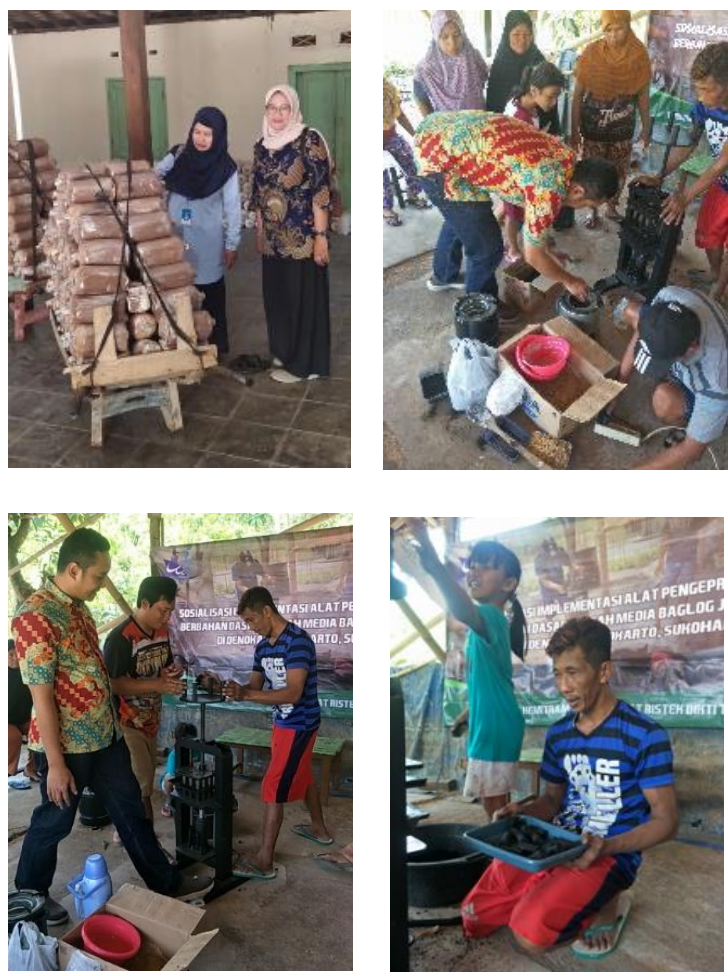

Gambar 13. Kegiatan Sosialisasi, Pelatihan dan Pendampingan Mitra

\section{KESIMPULAN}

Berdasarkan kegiatan Program Kemitraan Masyarakat (PKM) yang telah dilakukan oleh tim, kesimpulan yang dipaparkan adalah:

1. Implementasi teknologi tepat guna fasilitas produksi bio briket limbah baglog jamur yang terdiri dari alat pengepres dan kompor bio briket di Desa Polokarto berhasil diselesaikan dengan baik.

2. Alat pengepres bio briket berhasil di pakai oleh mitra untuk memproduksi briket media limbah baglog jamur tiram dengan kapasitas produksi $10 \mathrm{~kg}$ briket / jam.

3. Mitra pembudidaya telah mampu menggunakan dan merawat alat produksi bio briket dengan baik.

4. Tim PKM UNS telah melakukan sosialisasi dan pendampingan lapangan terkait pengemasan dan pemasaran bio briket. Akan tetapi kegiatan ini masih perlu ditingkatkan dan ditindaklanjuti dengan pelatihan dan pendampingan lanjutan terutama untuk sistem pemasaran digital (online).

\section{UCAPAN TERIMAKASIH}

Kegiatan program kemitraan masyarakat ini dilaksanakan dengan dana hibah Program Kemitraan Masyarakat (PKM) DIKTI tahun anggaran 2019 dengan nomor kontrak 720 /UN27.21/PM/2019.

\section{REFERENSI}

[1] R. W. Damayanti, C. N. Rosyidi, I. Priadythama, and A. Aisyati, "Alternatif Diversifikasi Pengolahan Jamur Tiram Putih ( Pleurotus Ostreatus ) menjadi Tepung Jamur," J. Performa, vol. 13, no. 2, pp. 127-134, 2014.

[2] S. Sumarsih, Untung Besar Usaha Bibit Jamur Tiram. Jakarta: Penebar Swadaya, 2010.

[3] N. Djarijah, Budi daya Jamur Tiram. Yogyakarta: Kanisius, 2001.

[4] U. S. Dharma, "Pemanfaatan Biomassa Limbah Jamur Tiram Sebagai Bahan Bakar Alternatif Untuk Proses Sterilisasi Jamur Tiram," Turbo, vol. 2, no. 2, pp. 17-22, 2013.

[5] S. Ghazali and P. Pratiwi, Usaha Jamur Tiram Skala Rumah Tangga. Jakarta: Penebar Swadaya, 2009.

[6] Kurniawan, Superkarbon Bahan Bakar Alternatif Pengganti Minyak Tanah dan Gas. Jakarta: Penebar Swadaya, 2008.

[7] P. Hakkila, Utilization of Residual Forest Biomass. Verlag Berlin: Springer, 1989.

[8] D. Irawati, N. N. Pradipta, and J. P. G. Sutapa, "Usaha Pemanfaatan Limbah Budi Daya Jamur sebagai Bahan Baku Teknologi Tepat Guna $\quad 275$ 
Pembuatan Briket di Kelompok Tani Jamur Sedyo Lestari Desa Argosari, Kecamatan Sedayu, Bantul," Indones. J. Community Engagem., vol. 02, no. No. 02, Maret 2017, pp. 175-188, 2017.

[9] S. Mushlihah, Sulfahri, R. S. Utami, E. Sunarto, and I. D. A. . Warmadewanthi, "Pengaruh Jenis Bahan Perekat Dan Metode Pengeringan Terhadap Kualitas
Briket Limbah Baglog Jamur Tiram Putih (Pleurotus ostreatus)," J. Biol. Res. Berk. Penelit. Hayati, vol. 17, pp. 47-51, 2011.

[10] U. Adan, Membuat Briket Bioarang. Yogyakarta: Kanisius, 1998. 